\title{
Defisit Air Pada Berbagai Fase Pertumbuhan dan Pengaruhnya Terhadap Karakter Kuantitatif Beberapa Genotipe Kacang Tanah
}

\section{Water Deficit in Different Phases of Growth and Their Effect on Quantitative Characteristics of Some Genotypes of Peanut}

\author{
A. Farid Hemon*, Sumarjan, Baiq Erna Listiana, Suprayanti Martia Dewi \\ Fakultas Pertanian, Universitas Mataram, Nusa Tenggara Barat. \\ *Corresponding Author Email: faridhemon_1963@yahoo.com
}

Manuscript received: 08-12-2020. Accepted: 25-10-2021

\begin{abstract}
ABSTRAK
Penelitian ini bertujuan untuk mengetahui pengaruh defisit air pada berbagai fase pertumbuhan tanaman terhadap karakter kuantitatif beberapa genotipe kacang tanah. Penelitian ini menggunakan Rancangan Acak Lengkap-Petak Terbagi. Petak utama adalah defisit air pada berbagai fase pertumbuhandan sub petak adalah genotipe kacang tanah. Faktor defisit air terdiri dari 6 aras perlakuan: $d_{0}=$ tanpa defisit air, $d_{1}=$ defisit airdari awal perkecambahan sampai panen, $d_{2}=$ defisit airdari awal perkecambahan sampai umur 25 hari setelah tanam (hst)atau fase vegetatif, $d_{3}=$ defisit air dari umur 26 hst sampai umur 50 hst atau fase pembungaan sampai pembentukan polong, $\mathrm{d}_{4}=$ defisit air dari umur 51 hst sampai umur 75 hst atau fase pengisian biji, dan $\mathrm{d}_{5}=$ defisit air dari umur $75 \mathrm{hst}$ sampai umur 100 hst atau fase pematangan biji sampai panen. Genotipe kacang tanah yang digunakan terdiri dari 10 genotipe. Hasil penelitian menunjukkan bahwa defisit air pada berbagai fase pertumbuhan tanaman menghasilkan karakter kuantitatif yang berbeda pada beberapa genotipe kacang tanah. Genotipe G3T4 mampu menghasilkan berat polong kering $12.7 \mathrm{~g}$ per tanaman terberat pada defisit airdari awal perkecambahan sampai panen. Genotipe G200-I menghasilkan berat polong kering $11.5 \mathrm{~g}$ per tanaman terberat pada defisit airfase vegetatif.Genotipe G3T4 menghasilkan berat polong kering $13.3 \mathrm{~g}$ per tanaman terberat pada defisit airfase generatif. Genotipe G300-II menghasilkan berat polong kering $11.7 \mathrm{~g}$ per tanaman terberat pada defisit air fase pengisian biji. Genotipe G2D2, G2T3 dan G200-I menghasilkan berat polong kering 11.0 g per tanaman terberat pada defisit air fase pematangan biji.
\end{abstract}

Kata kunci: cekaman kekeringan; defisit air; fotosintesis; hibridisasi

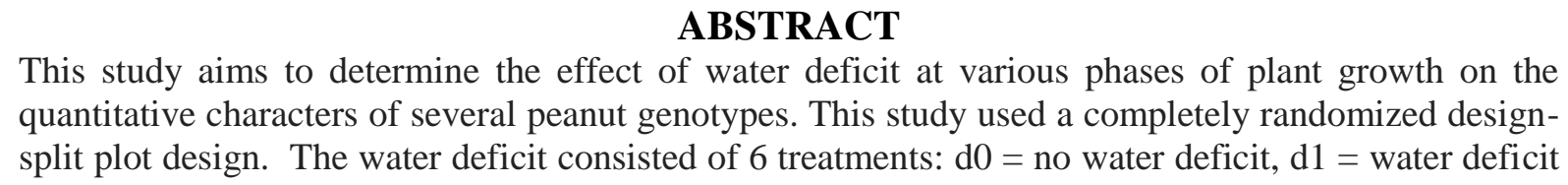


from germination to harvest, $\mathrm{d} 2=$ water deficit from germination to age 25 days after planting (dap) (vegetative phase), $\mathrm{d} 3=$ water deficit from age 26 to 50 dap (flowering phase to pod formation), $\mathrm{d} 4=$ water deficit from age 51 dap to 75 dap (seed filling phase), and d5 = water deficit from age 75 dap to 100 dap (seed ripening phase until harvest). The peanut genotype used consisted of 10 genotypes. The results showed that water deficit in various phases of plant growth resulted in different quantitative characters in several peanut genotypes. Genotype G3T4 produced heaviest dry pod weight of $12.7 \mathrm{~g}$ plant $^{-1}$ in water deficit from germination to harvest. Genotype G200-I produced heaviest dry pod weight of $11.5 \mathrm{~g}$ per plant $^{-1}$ in water deficit in the vegetative phase. Genotype G3T4 produced heaviest dry pod weight of $13.3 \mathrm{~g}$ per plant in water deficit the generative phase. Genotype G300-II produced heaviest the dry pod weight of $11.7 \mathrm{~g}_{\text {per }}$ plant $^{-1}$ in the water deficit of the seed filling phase. Genotypes G2D2, G2T3 and G200-I produced the heaviest dry pod weight of $11.0 \mathrm{~g}_{\text {per }}$ plant $^{-1}$ in the water deficit of the seed ripening phase.

Key words: drought; hybridization; photosynthesis; water deficit

\section{PENDAHULUAN}

Pengembangan kacang tanah saat ini, sebagian besar diarahkan pada lahan-lahan marginal seperti lahan kering. Penanaman kacang tanah di lahan kering sering menimbulkan cekaman kekeringan akibat menurunnya ketersediaan air tanah. Stres kekeringan telah menjadi faktor lingkungan utama yang berkontribusi terhadap penurunan produktivitas pertanian termasuk tanaman kacang tanah. Kekeringan mempengaruhi membran lipid dan respon fotosintesis (Lauriano, et al., 2000) dan hasil dalam kacang tanah (Meisner, 1991). Defisit air mempengaruhi transpor elektron tilakoid, fosforilasi, karboksilasi dan fotosintesis. Tanaman yang mengalami stres air akan mempengaruhi kadar lipid dan komposisinya dan ini meningkatkan permeabilitas membran. Mempertahankan integritas membran dalam kondisi kekeringan akan menentukan ketahanan tanaman terhadap stress (Kambiranda, et al., 2011).

Defisit air sangat dapat menghambat pertumbuhan dan produksi tanaman. Cekaman kekeringan berpengaruh terhadap aspek pertumbuhan tanaman meliputi anatomis, morfologis, fisiologis dan biokimia tanaman (Raper dan Kramer, 1987). Pada fase pertumbuhan vegetatif, ketersediaan air berpengaruh terhadap menurunnya kecepatan fotosintesis dan luas daun. Tanaman yang terkena cekaman kekeringan menyebabkan potensial air daun menurun, pembentukan klorofil terganggu (Alberte, et al., 1977) dan terbukti menurunkan produksi saat panen.

Penggunaan kultivar yang toleran terhadap kekeringan merupakan alternatif untuk peningkatan produksi kacang tanah. Penggunaan kultivar toleran pada budidaya kacang tanah di lahan cekaman kekeringan lebih efisien dan praktis dibandingkan dengan teknik budidaya yang lain. Hasil penelitian Hemon et al. (2018-2019) telah mendapatkan beberapa galur kacang tanah generasi F4 hasil persilangan antara kultivar toleran naungan dengan toleran kekeringan. Pada penelitian ini ingin mempelajari pengaruh cekaman kekeringann yang terjadi pada berbagai fase pertumbuhan tanaman terhadap karakter kuantitatif dan daya hasil beberapa genotipe kacang tanah.

Fase pertumbuhan tanaman mempunyai respon yang berbeda terhadap kekeringan. Tingkat kehilangan hasil akibat kekeringan (25\% dari kapasitas lapang) selama fase generatif (tanaman berumur 45 hari setelah tanam hingga panen) berkisar antara 8,3-37,3\% untuk tipe Spanish dan 8,7-42,2\% untuk tipe Valencia (Purnomo, et al., 2007). Kebutuhan air pada kacang tanah beragam tergantung pada fase pertumbuhan. Fase perkecambahan dan perkembangan polong dan biji membutuhkan air tersedia dalam tanah paling besar $(60 \%)$, sedang fase vegetatif dan fase pemasakan membutuhkan lebih sedikit air tersedia dalam tanah (40\%) (Ross, 2007). Benih harus menyerap air sekitar 50\% dari beratnya agar dapat 
berkecambah. Jika air tidak tersedia dalam jumlah yang cukup maka perkecambahan dapat tertunda sampai tiga minggu. Selama fase vegetatif, kebutuhan air pada tanaman kacang tanah relatif rendah dan akan meningkat selama periode perkembangan pembungaan, pembentukan ginofor dan awal pembentukan polong (Nautiyal, et al., 2011). Pada fase vegetatif, tanaman kacang tanah dapat hidup dengan sedikit air, asalkan memiliki keragaan yang seragam dan perkembangan sistem akar yang sehat.Awal pembungaan tidak tertunda oleh cekaman kekeringan (Boote dan Ketring, 1990). Tingkat produksi bunga berkurang oleh stres kekeringan selama berbunga tetapi jumlah totalbunga per tanaman tidak terpengaruh karena peningkatan durasi berbunga (Meisner, 1991).

Perbedaan fase pertumbuhan tanaman beberapa genotype kacang tanah diduga memberikan respon yang berbeda terhadap defisit air. Oleh karena itu, penelitian ini bertujuan untuk mengetahui pengaruh defisit air pada berbagai fase pertumbuhan tanaman terhadap karakter kuantitatif beberapa genotipe kacang tanah.

\section{BAHAN DAN METODE}

\section{Rancangan Percobaan}

Penelitian ini telah dilaksanakan di Screen House Teaching Farm Fakultas Pertanian Universitas Mataram dari bulan Juni sampai September 2020. Penelitian ini telah dilaksanakan dengan menggunakan Rancangan Acak Lengkap-Petak Terbagi. Petak utama adalah pengurangan pemberian air pada berbagai fase pertumbuhandan sub petak adalah genotipe kacang tanah. Faktor defisit air terdiri dari 6 aras perlakuan: $\mathrm{d}_{0}=$ tanpa defisit air, $\mathrm{d}_{1}=$ defisit air dari awal perkecambahan sampai panen, $\mathrm{d}_{2}=$ defisit airdari awal perkecambahan sampai umur 25 hari setelah tanam (hst) atau fase vegetatif, $d_{3}=$ defisit air dari umur 26 hst sampai umur 50 hst atau fase pembungaan sampai pembentukan polong, $\mathrm{d}_{4}=$ defisit air dari umur 51 hst sampai umur 75 hst atau fase pengisian biji, dan $\mathrm{d}_{5}=$ defisit air dari umur 75 hst sampai umur 100 hst atau fase pematangan biji sampai panen. Genotipe kacang tanah yang digunakan terdiri dari 10 genotipe. Setiap kombinasi perlakuan dibuat dalam 3 ulangan.

\section{Pelaksanaan Percobaan}

Benih yang digunakan dalam penelitian ini adalah benih hasil hibridisasi galur G300-II dan G200-I dengan cv. Domba, Bison, Takar I generasi F4. Benih-benih ini dipilih yang tua dan berkualitas.

Polibeg yang berisi tanah $(10 \mathrm{Kg})$ hasil ayakan disiapkan di dalam rumah kaca. Media tanam dipupuk dengan pupuk majemuk NPK (15-15-15) 3,2 g per polibeg atau $75 \mathrm{~kg}$ per hektar. Tiap polibeg ditanam dengan 2 biji dan pada lubang tanam ditaburi Furadan 3G. Penempatan polibeg diatur sehingga mengikuti jarak tanam 40x20 cm. Benih turunan F4 ditanam pada kondisi cekaman kekeringan dan sebagian yang lain ditanam pada kondisi tanpa cekaman kekeringan (kondisi optimum).

Perlakuan cekaman kekeringan dilakukan sebagai berikut. Semua tanaman disiram sampai kapasitas lapang dari awal tanam sampai umur 5 hari. Kapasitas lapang ditentukan dengan menyiram air pada media tanam sampai jenuh. Kejenuhan air ditunjukkan dengan menetesnya air pada lubang aerasi dasar polibeg. Perlakuan cekaman kekeringan diberikan mulai benih berkecambah (umur 5 hari) sampai panen (100 hst). Pada saat tanaman memasuki umur 5 hst, sebagian tanaman tidak mengalami cekaman kekeringan (tanaman dalam kondisi lengas tanah kapasitas lapang) dan sebagian perlakuan yang lain dipelihara dalam kondisi cekaman kekeringan sebagai akibat pengurangan pemberian air. 
Tanaman yang mengalami cekaman kekeringan disiram kembali dengan air sampai kapasitas lapang setiap 7-10 hari sekali (sehari setelah ada 70\% gejala layu pada daun). Gejala layu mulai terjadi ketika kandungan air tanah mencapai < 60-70\%dari kapasitas lapang yang dihitung berdasarkan selisih berat jumlah air yang disiramkan untuk mencapai kapasitas lapang dan saat tanaman mulai layu. Kadar air tanah sehari setelah saat layu sekitar 30-40\%, Perlakuan cekaman kekeringan diberikan sampai tanaman berumur 100 hst. Air diberikan kembali sehari setelah mengalami kelayuan (Hemon, 2006).

Pemeliharaan tanaman meliputi pembumbunan, pengendalian gulma, pengendalian hama, penyakit serta penyiraman. Tanaman pada umur 25 hst dibunbun dan membersihkan gulma yang ada di sekitar tanaman. Pengendalian hama dilakukan dengan menggunakan insektisida Bestfast 250 EC dan pengendalian penyakit dengan menggunakan Bestartop 325 SC. Penyiraman dilakukan berdasarkan perlakuan cekaman kekeringan.

\section{HASIL DAN PEMBAHASAN}

Ketersediaan air merupakan pembatas utama produksi kacang tanah. Tanaman akan terganggu pertumbuhannya ketika ketersediaan air dipermukaan akar berkurang. Defisit air mempengaruhi penampilan karakter kuatitatif beberapa genotipe kacang tanah. Respon genotipe tanaman yang toleran terhadap defisit air akan berbeda. Sampai dengan tingkatan yang masih dapat ditolerir oleh genotipe tanamannya, defisit air tidak akan mempengaruhi pertumbuhan dan perkembangan genotipe yang toleran (Kambiranda, et al., 2011).

Pada penelitian ini yang dimaksud dengan karakter kuntitatif adalah jumlah daun, jumlah cabang, tinggi tanaman, panjang akar, berat kering akar, berat kering polong, dan jumlah polong. Hasil penelitian menunjukkan bahwa defisit air pada berbagai fase pertumbuhan tanaman menghasilkan karakter kuantitatif yang berbeda pada beberapa genotipe kacang tanah terutama pada karakter kuantitatif komponen hasil dan daya hasil. Defisit air tidak berinteraksi secara nyata dengan genotipe pada tinggi tanaman dan jumlah daun, namun berinteraksi secara nyata pada jumlah cabang. Pada Tabel 1 dan 2 terlihat bahwa semua genotipe kacang tanah cenderung memperlihatkan tinggi tanaman yang lebih pendek dan jumlah daun yang lebih sedikit pada defisit air dari awal perkecambahan sampai panen.

Tabel 1. Tinggi tanaman $(\mathrm{cm})$ pada berbagai defisit air pada berbagai fase pertumbuhan tanaman

\begin{tabular}{ccccccc}
\hline Genotipe & \multicolumn{7}{c}{ Defisit air } \\
\cline { 2 - 7 } & $\mathrm{d} 0$ & $\mathrm{~d} 1$ & $\mathrm{~d} 2$ & $\mathrm{~d} 3$ & $\mathrm{~d} 4$ & $\mathrm{~d} 5$ \\
\hline G2T5 & 41.1 & 34.9 & 43.0 & 35.3 & 40.3 & 39.3 \\
G3D6 & 43.6 & 36.7 & 45.1 & 37.2 & 41.9 & 37.2 \\
G2D2 & 46.6 & 40.8 & 45.5 & 42.1 & 47.2 & 40.8 \\
G5-UII & 46.7 & 43.6 & 44.4 & 42.8 & 46.2 & 38.4 \\
G300-II & 41.6 & 38.7 & 39.6 & 39.6 & 38.9 & 34.3 \\
G2T3 & 45.9 & 39.7 & 45.3 & 40.3 & 47.4 & 43.7 \\
G11-UI & 43.8 & 39.2 & 45.5 & 42.1 & 48.1 & 43.8 \\
G3T4 & 46.3 & 37.8 & 43.8 & 40.6 & 45.6 & 40.4 \\
G200-I & 40.6 & 32.5 & 41.4 & 38.6 & 41.5 & 36.1 \\
G12-UI & 44.0 & 40.1 & 44.8 & 38.2 & 42.1 & 39.8 \\
\hline
\end{tabular}

Keterangan: Tinggi tanaman diamati pada umur 90 hst

$\mathrm{d}_{0}=$ tanpa defisit air, $\mathrm{d}_{1}=$ defisit air dari awal perkecambahan sampai panen, $\mathrm{d}_{2}=$ defisit airdari awal perkecambahan sampai umur 25 hari setelah tanam (hst), $d_{3}=$ defisit air dari umur 26 hst sampai umur $50 \mathrm{hst}, \mathrm{d}_{4}=$ defisit air dari umur 51 hst sampai umur 75 hst, $\mathrm{d}_{5}=$ defisit air dari umur 75 hst sampai umur 100 hst 
Tabel 2. Jumlah daun (lembar) pada berbagai defisit air pada berbagai fase pertumbuhan tanaman

\begin{tabular}{ccccccc}
\hline Genotipe & \multicolumn{7}{c}{ Defisit air } \\
\cline { 2 - 7 } & $\mathrm{d} 0$ & $\mathrm{~d} 1$ & $\mathrm{~d} 2$ & $\mathrm{~d} 3$ & $\mathrm{~d} 4$ & $\mathrm{~d} 5$ \\
\hline G2T5 & 38.3 & 28.0 & 48.3 & 30.7 & 50.5 & 35.8 \\
G3D6 & 47.3 & 42.0 & 41.0 & 44.3 & 45.5 & 39.0 \\
G2D2 & 45.3 & 44.3 & 40.7 & 40.0 & 64.5 & 36.5 \\
G5-UII & 46.5 & 34.7 & 48.0 & 47.3 & 46.8 & 44.2 \\
G300-II & 46.7 & 43.7 & 43.7 & 45.0 & 92.7 & 36.7 \\
G2T3 & 40.0 & 23.3 & 41.3 & 45.0 & 50.3 & 33.7 \\
G11-UI & 45.0 & 35.0 & 38.7 & 47.8 & 54.3 & 3.25 \\
G3T4 & 45.5 & 40.0 & 38.7 & 37.8 & 72.8 & 48.0 \\
G200-I & 41.3 & 33.7 & 46.7 & 49.2 & 72.0 & 39.7 \\
G12-UI & 38.8 & 40.3 & 34.7 & 45.7 & 44.2 & 35.7 \\
\hline
\end{tabular}

Keterangan: Jumlah daun tanaman diamati pada umur 90 hst

$d_{0}=$ tanpa defisit air, $d_{1}=$ defisit air dari awal perkecambahan sampai panen, $d_{2}=$ defisit airdari awal perkecambahan sampai umur 25 hari setelah tanam (hst), $\mathrm{d}_{3}=$ defisit air dari umur 26 hst sampai umur $50 \mathrm{hst}, \mathrm{d}_{4}=$ defisit air dari umur 51 hst sampai umur 75 hst, $\mathrm{d}_{5}=$ defisit air dari umur 75 hst sampai umur $100 \mathrm{hst}$

Pada Tabel 3 terlihat bahwa beberapa genotipe menunjukkan respon yang berbeda terhadap defisit air. Semua genotipe menghasilkan cabang yang jumlahnya sedikit pada defisit air dari awal perkecambahan sampai panen. Defisit air dapat menginduksi perubahan struktur tanaman mulai dari adaptasi morfologi (penurunan laju pertumbuhan, sistem perakaran dalam, dan modifikasi rasio akar ke pucuk untuk menghindari pengeringan) serta fisiologis dan metabolik respon (Hund, et al., 2009).

Tabel 3. Jumlah cabang pada berbagai defisit air pada berbagai fase pertumbuhan tanaman

\begin{tabular}{ccccccc}
\hline \multirow{2}{*}{ Genotipe } & \multicolumn{7}{c}{ Defisit air } \\
\cline { 2 - 7 } & $\mathrm{d} 0$ & $\mathrm{~d} 1$ & $\mathrm{~d} 2$ & $\mathrm{~d} 3$ & $\mathrm{~d} 4$ & $\mathrm{~d} 5$ \\
\hline G2T5 & $6.2 \mathrm{aB} *)$ & $4.3 \mathrm{bB} *)$ & $6.9 \mathrm{aA} *$ & $6.8 \mathrm{aA} *)$ & $7.2 \mathrm{aA} *$ & $7.2 \mathrm{aAB} *)$ \\
G3D6 & $8.3 \mathrm{aA}$ & $5.2 \mathrm{bB}$ & $6.8 \mathrm{aA}$ & $6.8 \mathrm{aA}$ & $5.7 \mathrm{bB}$ & $7.8 \mathrm{aA}$ \\
G2D2 & $6.0 \mathrm{aB}$ & $5.7 \mathrm{aAB}$ & $5.7 \mathrm{aB}$ & $5.5 \mathrm{aB}$ & $6.7 \mathrm{aAB}$ & $5.7 \mathrm{aB}$ \\
G5-UII & $7.2 \mathrm{aA}$ & $5.7 \mathrm{bAB}$ & $7.5 \mathrm{aA}$ & $7.7 \mathrm{aA}$ & $7.0 \mathrm{aA}$ & $7.8 \mathrm{aA}$ \\
G300-II & $6.8 \mathrm{aAB}$ & $6.5 \mathrm{aA}$ & $6.8 \mathrm{aA}$ & $6.8 \mathrm{aA}$ & $7.5 \mathrm{aA}$ & $6.3 \mathrm{aAB}$ \\
G2T3 & $6.5 \mathrm{aB}$ & $6.5 \mathrm{aA}$ & $6.7 \mathrm{aA}$ & $6.8 \mathrm{aA}$ & $6.7 \mathrm{aAB}$ & $6.8 \mathrm{aAB}$ \\
G11-UI & $7.0 \mathrm{aA}$ & $6.5 \mathrm{aA}$ & $6.8 \mathrm{aA}$ & $7.2 \mathrm{aA}$ & $7.5 \mathrm{aA}$ & $7.7 \mathrm{aA}$ \\
G3T4 & $6.2 \mathrm{abB}$ & $5.5 \mathrm{bB}$ & $5.7 \mathrm{bAB}$ & $6.5 \mathrm{abA}$ & $7.7 \mathrm{aA}$ & $7.2 \mathrm{aAB}$ \\
G200-I & $5.5 \mathrm{bB}$ & $5.0 \mathrm{bB}$ & $5.8 \mathrm{abAB}$ & $7.7 \mathrm{aA}$ & $6.0 \mathrm{abB}$ & $7.0 \mathrm{aAB}$ \\
G12-UI & $7.8 \mathrm{aA}$ & $6.3 \mathrm{aA}$ & $5.0 \mathrm{bB}$ & $7.5 \mathrm{aA}$ & $6.3 \mathrm{aB}$ & $7.0 \mathrm{aAB}$ \\
\hline
\end{tabular}

Keterangan: Jumlah daun tanaman diamati pada umur 90 hst

*)Angka-angka yang diikuti oleh huruf kecil sama pada baris yang sama tidak berbeda nyata, dan angka-angka yang diikuti oleh huruf kapital yang sama pada kolom yang sama tidak berbeda nyata $\mathrm{d}_{0}=$ tanpa defisit air, $\mathrm{d}_{1}=$ defisit air dari awal perkecambahan sampai panen, $\mathrm{d}_{2}=$ defisit air dari awal perkecambahan sampai umur 25 hari setelah tanam (hst), $d_{3}=$ defisit air dari umur 26 hst sampai umur 50 hst, $\mathrm{d}_{4}=$ defisit air dari umur 51 hst sampai umur 75 hst, $\mathrm{d}_{5}=$ defisit air dari umur 75 hst sampai umur 100 hst 
Defisit air mempengaruhi pertumbuhan polong kacang tanah. Pada Tabel 4 terlihat bahwa defisit air secara keseluruhan pertumbuhan polong terutama defisit air dari awal perkecambahan sampai panen. Pada penelitian ini terlihat pula bahwa defisit air dari awal perkecambahan sampai panen (d1) menurunkan berat polong kering sampai 21,3\% (data primer dihitung) dibanding tanpa defisit air. Defisit air menurunkan berat polong kering pada fase vegetatif (d2) sampai 20,3\%, pada fase generatif (d3) sampai $27,7 \%$, pada fase pengisian biji (d4) sampai $24,3 \%$ dan ada fase pematangan biji (d5) sampai 15,1\%. Defisit air pada berbagai fase pertumbuhan juga mempengaruhi jumlah polong. Masing-masing genotipe juga menujukkan karakter kuantitatif jumlah polong yang berbeda pada pemberian defisit air pada berbagai fase pertumbuhan (Tabel 5). Penelitian lain menunjukkan pula bahwa kekurangan air tanah mengurangi pertumbuhan polong dan biji kacang tanah sebesar $30 \%$ dan penurunan berat biji kira-kira 428-563 mg (Sexton, et al., 1997). Cekaman air menyebabkan pengurangan biomassa daun dan polong kering kacang tanah (Collino, et al., 2000) dan penurunan bobot kering polong diduga disebabkan oleh proses terhambatnya inisiasi dan pemanjangan ginofor (Chapman, et al., 1993). Cekamam kekeringan juga menghambat penetrasi ginofor dan pengembangan polong sehingga menurunkan hasil tanaman dan besarnya penurunan hasil sangat tergantung kultivar kacang tanah (Jogloy, et al., 1996).

Tabel 4. Berat kering polong (g) per tanaman pada berbagai defisit air pada berbagai fase pertumbuhan tanaman

\begin{tabular}{ccccccc}
\hline Genotipe & \multicolumn{7}{c}{ Defisit air } \\
\cline { 2 - 7 } & $\mathrm{d} 0$ & $\mathrm{~d} 1$ & $\mathrm{~d} 2$ & $\mathrm{~d} 3$ & $\mathrm{~d} 4$ & $\mathrm{~d} 5$ \\
\hline G2T5 & $8.3 \mathrm{aA} \mathrm{A}^{*}$ & $8.2 \mathrm{aA} \mathrm{A}^{*}$ & $8.3 \mathrm{aA} \mathrm{A}^{*}$ & $4.7 \mathrm{aB} \mathrm{B}^{*}$ & $10.2 \mathrm{aA} \mathrm{A}^{*}$ & $9.5 \mathrm{aA} \mathrm{A}^{*}$ \\
G3D6 & $11.0 \mathrm{aA}$ & $10.2 \mathrm{aA}$ & $10.3 \mathrm{aA}$ & $7.0 \mathrm{aAB}$ & $8.3 \mathrm{aA}$ & $10.0 \mathrm{aA}$ \\
G2D2 & $13.3 \mathrm{aA}$ & $7.7 \mathrm{aA}$ & $8.7 \mathrm{aA}$ & $9.1 \mathrm{aAB}$ & $9.0 \mathrm{aA}$ & $11.0 \mathrm{aA}$ \\
G5-UII & $12.0 \mathrm{aA}$ & $7.5 \mathrm{abAB}$ & $10.0 \mathrm{aA}$ & $5.3 \mathrm{bAB}$ & $10.5 \mathrm{aA}$ & $8.2 \mathrm{abAB}$ \\
G300-II & $10.3 \mathrm{aA}$ & $9.7 \mathrm{aA}$ & $9.0 \mathrm{aA}$ & $11.2 \mathrm{aA}$ & $11.7 \mathrm{aA}$ & $10.3 \mathrm{aA}$ \\
G2T3 & $11.2 \mathrm{aA}$ & $6.5 \mathrm{abA}$ & $8.8 \mathrm{abA}$ & $5.8 \mathrm{bA}$ & $6.5 \mathrm{abA}$ & $10.9 \mathrm{aA}$ \\
G11-UI & $11.0 \mathrm{aA}$ & $8.8 \mathrm{aA}$ & $9.8 \mathrm{aA}$ & $7.0 \mathrm{aA}$ & $7.7 \mathrm{aA}$ & $9.3 \mathrm{aA}$ \\
G3T4 & $14.2 \mathrm{aA}$ & $12.7 \mathrm{abA}$ & $8.0 \mathrm{bA}$ & $13.3 \mathrm{abA}$ & $9.8 \mathrm{abA}$ & $10.0 \mathrm{abA}$ \\
G200-I & $14.2 \mathrm{aA}$ & $11.0 \mathrm{aA}$ & $11.5 \mathrm{aA}$ & $12.0 \mathrm{aA}$ & $8.5 \mathrm{aA}$ & $11.3 \mathrm{aA}$ \\
G12-UI & $10.8 \mathrm{aA}$ & $9.2 \mathrm{abA}$ & $8.3 \mathrm{abA}$ & $8.7 \mathrm{abA}$ & $5.8 \mathrm{bA}$ & $8.3 \mathrm{abA}$ \\
\hline
\end{tabular}

*)Angka-angka yang diikuti oleh huruf kecil sama pada baris yang sama tidak berbeda nyata, dan angka-angka yang diikuti oleh huruf kapital yang sama pada kolom yang sama tidak berbeda nyata $\mathrm{d}_{0}=$ tanpa defisit air, $\mathrm{d}_{1}=$ defisit airdari awal perkecambahan sampai panen, $\mathrm{d}_{2}=$ defisit air dari awal perkecambahan sampai umur 25 hari setelah tanam (hst), $d_{3}=$ defisit air dari umur 26 hst sampai umur 50 hst, $\mathrm{d}_{4}=$ defisit air dari umur 51 hst sampai umur 75 hst, $\mathrm{d}_{5}=$ defisit air dari umur 75 hst sampai umur 100 hst 
Tabel 5. Jumlah polong per tanaman pada berbagai defisit air pada berbagai fase pertumbuhan tanaman

\begin{tabular}{ccccccc}
\hline Genotipe & \multicolumn{7}{c}{ Defisit air } \\
\cline { 2 - 7 } & $\mathrm{d} 0$ & $\mathrm{~d} 1$ & $\mathrm{~d} 2$ & $\mathrm{~d} 3$ & $\mathrm{~d} 4$ & $\mathrm{~d} 5$ \\
\hline G2T5 & $7.2 \mathrm{abB}$ & $5.8 \mathrm{bB}$ & $7.5 \mathrm{abB}$ & $8.3 \mathrm{abA}$ & $9.7 \mathrm{aA}$ & $9.3 \mathrm{aAB}$ \\
G3D6 & $10.5 \mathrm{aA}$ & $7.3 \mathrm{aB}$ & $10.5 \mathrm{aA}$ & $8.3 \mathrm{aA}$ & $10.5 \mathrm{aA}$ & $9.2 \mathrm{aAB}$ \\
G2D2 & $8.8 \mathrm{aAB}$ & $7.7 \mathrm{aB}$ & $6.0 \mathrm{aB}$ & $7.8 \mathrm{aA}$ & $9.5 \mathrm{aA}$ & $8.8 \mathrm{aAB}$ \\
G5-UII & $10.8 \mathrm{aA}$ & $9.3 \mathrm{aA}$ & $9.5 \mathrm{aA}$ & $9.8 \mathrm{aA}$ & $11.3 \mathrm{aA}$ & $9.0 \mathrm{aAB}$ \\
G300-II & $9.5 \mathrm{aA}$ & $9.3 \mathrm{aA}$ & $9.2 \mathrm{aA}$ & $8.3 \mathrm{aA}$ & $10.5 \mathrm{aA}$ & $7.8 \mathrm{aB}$ \\
G2T3 & $8.5 \mathrm{aAB}$ & $7.7 \mathrm{aB}$ & $7.2 \mathrm{aB}$ & $7.7 \mathrm{aA}$ & $7.5 \mathrm{aB}$ & $8.8 \mathrm{aAB}$ \\
G11-UI & $10.5 \mathrm{aA}$ & $8.3 \mathrm{aAB}$ & $9.8 \mathrm{aA}$ & $9.2 \mathrm{aA}$ & $11.3 \mathrm{aA}$ & $9.2 \mathrm{aAB}$ \\
G3T4 & $7.0 \mathrm{aB}$ & $10.2 \mathrm{aA}$ & $6.7 \mathrm{aB}$ & $6.8 \mathrm{aB}$ & $8.0 \mathrm{aAB}$ & $7.5 \mathrm{aB}$ \\
G200-I & $11.7 \mathrm{aA}$ & $11.5 \mathrm{aA}$ & $7.7 \mathrm{bB}$ & $10.2 \mathrm{abA}$ & $9.7 \mathrm{abA}$ & $9.7 \mathrm{abAB}$ \\
G12-UI & $10.3 \mathrm{aA}$ & $10.5 \mathrm{aA}$ & $6.0 \mathrm{bB}$ & $10.5 \mathrm{aA}$ & $11.3 \mathrm{aA}$ & $12.7 \mathrm{aA}$ \\
\hline
\end{tabular}

*)Angka-angka yang diikuti oleh huruf kecil sama pada baris yang sama tidak berbeda nyata, dan angka-angka yang diikuti oleh huruf kapital yang sama pada kolom yang sama tidak berbeda nyata $\mathrm{d}_{0}=$ tanpa defisit air, $\mathrm{d}_{1}=$ defisit airdari awal perkecambahan sampai panen, $\mathrm{d}_{2}=$ defisit air dari awal perkecambahan sampai umur 25 hari setelah tanam (hst), $\mathrm{d}_{3}=$ defisit air dari umur 26 hst sampai umur 50 hst, $\mathrm{d}_{4}=$ defisit air dari umur 51 hst sampai umur 75 hst, $\mathrm{d}_{5}=$ defisit air dari umur 75 hst sampai umur 100 hst

Bobot kering dan panjang akar merupakan indikator kemampuan tanaman untuk dapat bertahan pada kondisi kekurangan air. Jumlah akar yang banyak dan panjang akan dapat membantu dalam menyerap air untuk proses pertumbuhan tanaman. Menurut Kusvuran (2011) bahwa cekaman kekeringan dapat mengganggu permeabilitas membran-membran sel akar yang menyebabkan terhambatnya pertumbuhan tanaman terutama bagian perakaran tanaman sehingga secara tidak langsung defisit air dapat menurunkan bobot kering akar.

Tabel 6. Panjang akar $(\mathrm{cm})$ per tanaman pada berbagai defisit air pada berbagai fase pertumbuhan tanaman

\begin{tabular}{ccccccc}
\hline Genotipe & \multicolumn{7}{c}{ Defisit air } \\
\cline { 2 - 7 } & $\mathrm{d} 0$ & $\mathrm{~d} 1$ & $\mathrm{~d} 2$ & $\mathrm{~d} 3$ & $\mathrm{~d} 4$ & $\mathrm{~d} 5$ \\
\hline G2T5 & $30.3 \mathrm{bB}$ & $25.6 \mathrm{bA}$ & $30.3 \mathrm{bA}$ & $46.4 \mathrm{aA}$ & $31.0 \mathrm{bA}$ & $33.6 \mathrm{bA}$ \\
G3D6 & $37.7 \mathrm{abA}$ & $22.9 \mathrm{cA}$ & $34.2 \mathrm{abA}$ & $42.0 \mathrm{aA}$ & $29.7 \mathrm{bA}$ & $32.5 \mathrm{abA}$ \\
G2D2 & $30.0 \mathrm{aB}$ & $29.0 \mathrm{aA}$ & $33.6 \mathrm{aA}$ & $36.7 \mathrm{aA}$ & $38.0 \mathrm{aA}$ & $30.7 \mathrm{aA}$ \\
G5-UII & $31.0 \mathrm{aB}$ & $26.2 \mathrm{aA}$ & $28.3 \mathrm{aA}$ & $36.1 \mathrm{aA}$ & $28.2 \mathrm{aA}$ & $36.3 \mathrm{aA}$ \\
G300-II & $35.1 \mathrm{aB}$ & $31.7 \mathrm{aA}$ & $33.7 \mathrm{aA}$ & $33.0 \mathrm{aA}$ & $33.7 \mathrm{aA}$ & $35.9 \mathrm{aA}$ \\
G2T3 & $40.5 \mathrm{aAB}$ & $27.3 \mathrm{bA}$ & $28.3 \mathrm{bA}$ & $33.8 \mathrm{abA}$ & $30.6 \mathrm{abA}$ & $36.0 \mathrm{abA}$ \\
G11-UI & $48.6 \mathrm{aA}$ & $28.1 \mathrm{cA}$ & $34.3 \mathrm{bA}$ & $36.1 \mathrm{bA}$ & $39.5 \mathrm{abA}$ & $33.9 \mathrm{bA}$ \\
G3T4 & $30.0 \mathrm{bcB}$ & $25.8 \mathrm{cA}$ & $33.2 \mathrm{bcA}$ & $43.4 \mathrm{aA}$ & $38.1 \mathrm{abA}$ & $35.6 \mathrm{bA}$ \\
G200-I & $50.5 \mathrm{aA}$ & $35.3 \mathrm{bA}$ & $36.9 \mathrm{bA}$ & $41.6 \mathrm{abA}$ & $33.6 \mathrm{bA}$ & $32.4 \mathrm{bA}$ \\
G12-UI & $37.9 \mathrm{aA}$ & $30.5 \mathrm{aA}$ & $31.7 \mathrm{aA}$ & $35.3 \mathrm{aA}$ & $28.0 \mathrm{aA}$ & $31.4 \mathrm{aA}$ \\
\hline
\end{tabular}

*)Angka-angka yang diikuti oleh huruf kecil sama pada baris yang sama tidak berbeda nyata, dan angka-angka yang diikuti oleh huruf kapital yang sama pada kolom yang sama tidak berbeda nyata $\mathrm{d}_{0}=$ tanpa defisit air, $\mathrm{d}_{1}=$ defisit airdari awal perkecambahan sampai panen, $\mathrm{d}_{2}=$ defisit air dari awal perkecambahan sampai umur 25 hari setelah tanam (hst), $d_{3}=$ defisit air dari umur 26 hst sampai umur 50 hst, $\mathrm{d}_{4}=$ defisit air dari umur 51 hst sampai umur 75 hst, $\mathrm{d}_{5}=$ defisit air dari umur 75 hst sampai umur $100 \mathrm{hst}$ 
Berdasarkan pengamatan bahwa defisit air yang dialami oleh beberapa genotipe dari awal perkecambahan sampai panen (d1) memberikan akar yang terpendek dibanding genotipe tanpa defisit air (Tabel 6). Secara statistik, beberapa genotipe tidak memberikan berat kering akar yang berbeda pada defisit air pada berbagai fase pertumbuhan tanaman (Tabel 7). Namun ada kecenderungan bahwa genotipe yang berbeda memberikan berat kering akar yang lebih berat pada setiap defisit air pada berbagai fase pertumbuhan.

Tabel 7. Berat kering akar (g) per tanaman pada berbagai defisit air pada berbagai fase pertumbuhan tanaman

\begin{tabular}{ccccccc}
\hline Genotipe & \multicolumn{7}{c}{ Defisit air } \\
\cline { 2 - 7 } & $\mathrm{d} 0$ & $\mathrm{~d} 1$ & $\mathrm{~d} 2$ & $\mathrm{~d} 3$ & $\mathrm{~d} 4$ & $\mathrm{~d} 5$ \\
\hline G2T5 & 0.8 & 0.5 & 0.8 & 0.6 & 0.6 & 1.1 \\
G3D6 & 1.7 & 0.7 & 1.2 & 1.5 & 0.9 & 1.1 \\
G2D2 & 0.7 & 0.7 & 0.7 & 1.0 & 0.7 & 0.5 \\
G5-UII & 1.2 & 0.7 & 0.8 & 0.9 & 0.7 & 0.9 \\
G300-II & 1.0 & 1.0 & 0.7 & 0.8 & 1.1 & 1.1 \\
G2T3 & 1.1 & 0.5 & 0.5 & 0.8 & 0.7 & 0.9 \\
G11-UI & 1.0 & 0.7 & 0.7 & 0.8 & 1.1 & 1.1 \\
G3T4 & 0.9 & 1.0 & 0.8 & 0.9 & 1.0 & 1.5 \\
G200-I & 1.2 & 1.0 & 0.7 & 1.0 & 0.8 & 1.3 \\
G12-UI & 1.2 & 0.8 & 0.6 & 0.7 & 0.7 & 1.4 \\
\hline
\end{tabular}

Keterangan: $\mathrm{d}_{0}=$ tanpa defisit air, $\mathrm{d}_{1}=$ defisit airdari awal perkecambahan sampai panen, $\mathrm{d}_{2}=$ defisit air dari awal perkecambahan sampai umur 25 hari setelah tanam (hst), $\mathrm{d}_{3}=$ defisit air dari umur 26 hst sampai umur 50 hst, $\mathrm{d}_{4}=$ defisit air dari umur 51 hst sampai umur 75 hst, $\mathrm{d}_{5}=$ defisit air dari umur 75 hst sampai umur 100 hst

Pemanjangan akar pada kondisi cekaman kekeringan dimungkinkan karena tanaman memiliki mekanismie pengaturan perbandingan pertumbuhan tajuk akar (root and shoot ratio). Pada kondisi cekaman kekeringan tanaman akan menahan laju pertumbuhan tajuk dengan mensintesis hormon retardan yang menghambat pertumbuhan tajuk, sehingga memperbesar laju pertumbuhan akar. Mekanisme ini dilakukan tanaman untuk mencegah besarnya kehilangan air dari tanaman, sebab untuk perpanjangan akar diperlukan lebih sedikit air dibandingkan pemanjangan pucuk yang akan memperbesar proses respirasi dengan pembentukan daun. Proses pemanjang akar juga akan dapat menjangkau volume tanah yang lebih besar sehingga lebih banyak menyerap air (Levitt, 1980). Sebagaimana penelitian yang dilakukan oleh Djazuli (2010) bahwa tanaman yang mampu bertahan pada kondisi kekurangan air memiliki akar yang mampu tumbuh walaupun pada kondisi kekurangan air. Menurut Suardi (2002) bahwa perakaran berhubungan erat dengan sifat toleransi tanaman terhadap kekeringan. Sebagimana penelitian yang dilakukan oleh Hemon dan Sumarjan (2009), bahwa tanaman yang toleran terhadap cekaman PEG menghasilkan mekanisme toleran terutama pertumbuhan akar lebih baik. Hal ini dapat dilihat bahwa tanaman yang bergejala nekrosis besar pada daun merupakan akibat dari ketidakmampuan akar untuk mensuplai air pada daun tanaman. 


\section{KESIMPULAN}

Hasil penelitian menunjukkan bahwa defisit air pada berbagai fase pertumbuhan tanaman menghasilkan karakter kuantitatif yang berbeda pada beberapa genotipe kacang tanah. Genotipe G3T4 mampu menghasilkan berat polong kering terberat 12.7 g per tanaman pada defisit airdari awal perkecambahan sampai panen. Genotipe G200-I menghasilkan berat polong kering terberat $11.5 \mathrm{~g}$ per tanaman pada defisit airfase vegetatif. Genotipe G3T4 menghasilkan berat polong kering terberat 13.3 g per tanaman pada defisit airfase generatif. Genotipe G300-II menghasilkan berat polong kering terberat $11.7 \mathrm{~g}$ per tanaman pada defisit air fase pengisian biji. Genotipe G2D2, G2T3 dan G200-I menghasilkan berat polong kering terberat $11.0 \mathrm{~g}$ per tanaman pada defisit air fase pematangan biji.

\section{Ucapan Terima Kasih}

Penelitian ini terlaksana atas biaya PNBP Fakultas Pertanian Universitas Mataram Tahun 2020. Penulis menyampaikan ucapan terima kasih yang sebesar-besarnya atas dukungan dana tersebut.

\section{DAFTAR PUSTAKA}

Alberte RS, Thomber JP, Fiscus EL. 1977. Water stress effect on the content and organization of chlorophyll and bundle sheath chloroplast of maize. Plant Physiol. 59:351-352.

Boote, KJ. dan Ketring, DL., 1990. Peanut. In: Stewart B.A. and Nielson D.R. (Eds), Irrigation of Agricultural Crops. Asa-Groundnut - A Global Perspective. International Crops Research CSSA-SSSA, Madison.

Chapman SC, Ludlow MM, Blamey FPC, Fisher KS. 1993. Effect of drought at pod filling on utilization of water and growth of cultivars of groundnut. Fild Crop Res. 32:243255.

Collino DJ, Dardanelli JL, Sereno R, Racca RW. 2000. Physiological responses of Argentine peanut varieties to water stress. Water uptake and water use efficiency. Field Crop Res. 68:133-142.

Djazuli, M., 2010. Pengaruh Cekaman Kekeringan terhadap Pertumbuhan dan Beberapa Karakter Morfo-Fisiologis Tanaman Nilam. Bul. Littro. Vol. 21

Hemon, A. F., 2006. Efektifitas Seleksi In Vitro Berulang untuk Mendapatkan Plasma Nutfah Kacang Tanah Toleran terhadap Cekaman Kekeringan dan Resisten Terhadap Penyakit Busuk Batang Sclerotium rolfsii. Disertasi. Sekolah Pasca Sarjana IPB. Bogor. $200 \mathrm{~h}$.

Hemon, A. F. dan Sumarjan, 2009. Efektivitas Polietilena Glikol dan Manitol sebagai Agens Penyeleksi In Vitro untuk Cekaman Kekeringan terhadap Pertumbuhan Embrio Somatik Kacang Tanah. Crop Agro. Sumber: http://www.omrc-drn.or.id/kegiatanriset.html?rid=4380\&cid1 $=\&$ cid $=$. [17 Juli 2011]

Hemon, AF., Sumarjan, Hanafi AR. 2018-2019. Perbaikan Karakter Tanaman Kacang Tanah: Toleran Naungan dan Berdaya Hasil Tinggi (>3,0 Ton Polong Kering Per Hektar) di Lahan Kering. Laporan Penelitian Penelitian Terapan Unggulan Perguruan Tinggi Universitas Mataram. 
Hund, A, Ruta, N and Liedgens, M, 2009. Rooting depth and water use efficiency of tropical maize inbred lines, differing in drought tolerance. Plant and Soil, vol. 318, no. 1-2, pp. 311-325.

Jaleel, CA, Manivannan, P G, Lakshmanan, M.A, Gomathinayagam, M and Panneerselvam, $\mathrm{R}, 2008$. "Alterations in morphological parameters and photosynthetic pigment responses of Catharanthus roseus under soil water deficits," Colloids and Surfaces B: Biointerfaces, vol. 61, no. 2, pp. 298-303.

Jogloy, S., Patanothai, A, Toomsan, S dan Isleib, TG., 1996. Breeding peanut to fit into Thai cropping systems. Proc. of the Peanut Collaborative Research Support ProgramInternational Research Symposium and Workshop, Two Jima Quality Inn,Arlington, Virginia, USA, 25-31 March, 1996: pp 353-362.

Kusvuran, S., 2011. Effects of drought and salt stresses on growth, stomatal conductance, leaf water and osmotic potentials of melon genotypes (Cucumis melo L.). Website: http ://www.academicjournals.org/ajar/pdf/pdf2012/5\%20Feb/Kusvuran.pdf. [23 Juni 2012]

Kambiranda, DM, Hemanth, KN, Vasanthaiah, Katam,R, Ananga, A, Basha, SM and Naik,K, 2011. Impact of Drought Stress on Peanut (Arachis hypogaea L.) Productivity and Food Safety. Plants and Environment Edited by Dr. Hemanth Vasanthaiah ISBN 978-953-307-779-6 Hard cover, 272 pages Publisher InTech Published online 17, October, 2011 Published in print edition October, 2011.

Lauriano, JA, Lidon, FC, Carvalho, .A, Campos, PS and Matos, MDC, 2000. Drought Effects on Membrane Lipids And Photosynthetic Activity In Different Peanut Cultivars, Photosynthetica (Prague), 38: 7-12.

Levitt, J. 1980. Responses of plant to environmental stresses. London: Academic Press

Meisner, CA., 1991. Peanut Roots, Shoot and Yield and Water Stress. Dissertation Abstracts International. Biological Sciences and Engineering. 52 (1): 38-48.

Nautiyal, P.C., Y.C. Joshi and D. Dayal. 2011. Response of groundnut to deficit irrigation during vegetative growth. FAO Corporate Document Repository. http:/ /www.fao.org. (diakses 15 Maret 2011).

Purnomo, J, Trustinah dan N. Nugrahaeni, 2007. Tingkat kehilangan hasil kacang tanah tipe Spanish dan Valencia akibat kekeringan. Penelitian Pertanian Tanaman Pangan 26(2): 127-131.

Raper CD, Kramer PJ. 1987. Stress physiology. In: Wilcox JR, (Ed.). Soybean: improvement, production and uses. 2nd edition. New York, American Society of Agronomy, Inc. P $589-625$.

Ross, BB, 2007. Peanut Irrigation. http://pubs.ext. vt.edu. (Tanggal akses 15 April 2011).

Sexton, PJ., Benett, JM. dan Boote, KJ., 1997. The effect of dry use efficiency and carbon isotope discrimination in peanut under pegging zone soil on pod formation. Peanut Science, 24: 19-24.

Suardi, D., 2002. Perakaran Padi Dalam Hubungannya dengan Toleransi Tanaman Terhadap Kekeringan Dan Hasil. Balai Penelitian Bioteknologi dan Sumber Daya Genetik 
Pertanian. Jurnal Litbang Pertanian. Sumber:

http://pustaka.litbang.deptan.go.id/publikasi/p3213024.pdf . [12 Juli 2002]

Suther, DM and Patel, MS, 1992. Yield and Nutrient Absorption by Groundnut and Iron

Availability in Soil as Influenced By Lime and Soil Water. Journal of Indian Society of Soil Science, Vol.40, pp. 594-596 